MICHAŁ BORYCHOWSKI ANDRZEJ CZYŻEWSKI

\title{
Determinants of prices increase of agricultural commodities in a global context I
}

Michał Borychowski, Ph.D. Student Poznań University of Economics and Business Department of Macroeconomics and Agricultural Economics Professor Andrzej Czyżewski Poznań University of Economics and Business Department of Macroeconomics and Agricultural Economics

\section{Introduction}

Agricultural commodity prices are the result of the interaction of many factors, including basic aggregates of market - supply and demand. There are complex linkages between them and they are further modified and distorted by the action of government and government policies. Thus it is fully justified to say that the increases of agricultural raw materials' prices, which have taken place in recent years, were the result of many factors (Kretschmer, Bowyer and Buckwell 2012, p. 31). The chart below shows the global Food Price Index after 2002. In the period 2003-2008 prices of some agricultural commodities and food doubled. These increases were the highest and the broadest after World War II. It is also noted that these prices reached record highs or were close to maximum levels (Abbott, Hurt and Tyner 2008, p. 5, Baffes 2009, p. 2). After 2008 there was a certain decrease in prices, but in 2010 prices again were very high, and in 2011 they reached record-high levels, resulting in Food Price Index reached 169.1 (taking into

1 This article was financed by the National Science Centre granted on the basis of the decision number: UMO-2013/11/N/HS4/03194. 
account that the period 2002-2004 = 100). In 2014 the Food Price Index is lower than in the peaks, but still remains relatively high (higher than in 2007 and 2010).

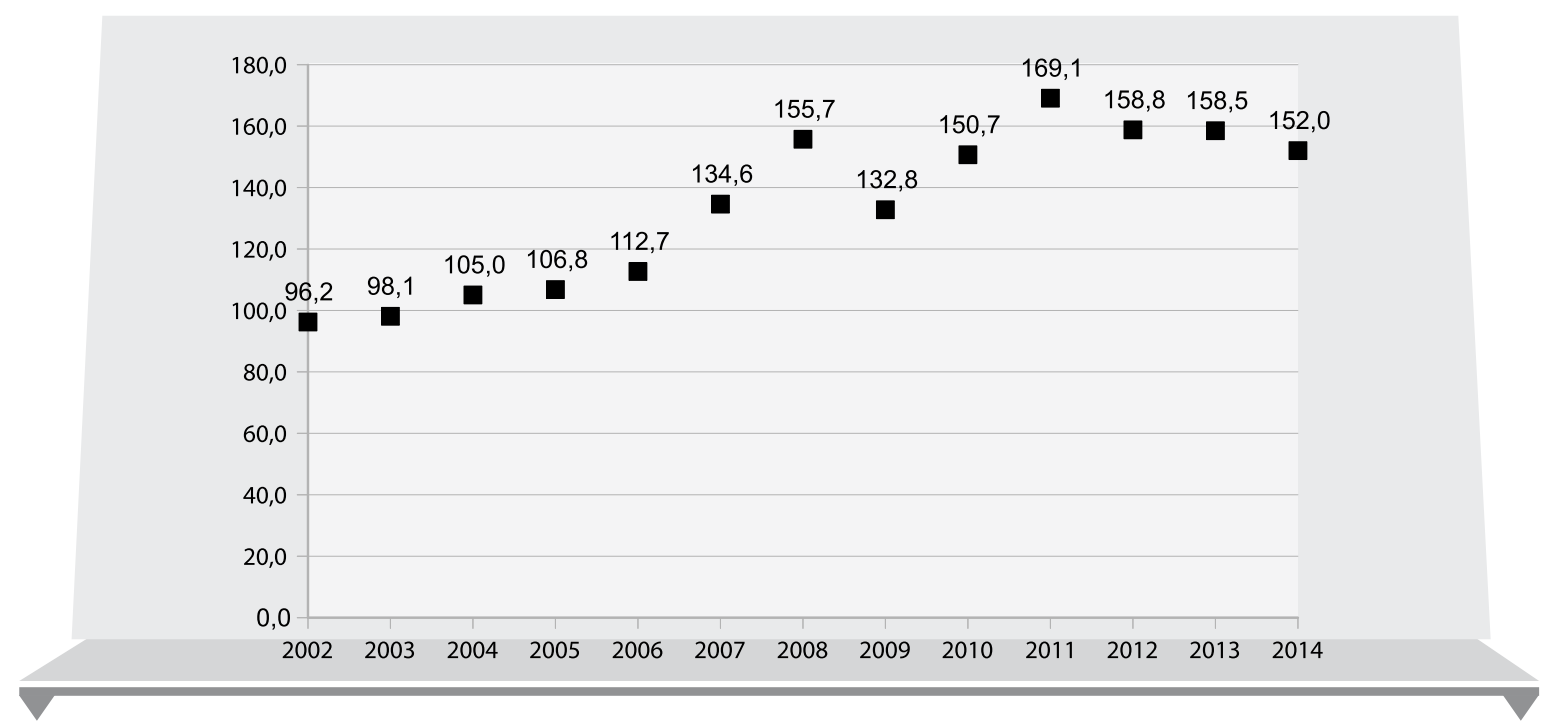

Figure 1. World Food Price Index in 2002-2014, real (2002-2004 $=100)$

Source: Oown study based on: Food and Agriculture Organization of the United Nations

One aim of this article is to present the price-determining factors in the agricultural markets. It will help to achieve the main objective, which is identifying factors that influenced the growth in agricultural commodity prices after 2006. In this article there was used a deductive method and it is a literature review paper. However this article provides an outlook on determinants that were the most important for the increases in last decade. Considerations are primarily global, and only some issues are associated with certain countries. These considerations concern the events after 2006, because a fundamental axis of the paper are determinants of increases in agricultural commodity prices in recent ten years. However some of them concern universal factors, thus they go back to previous years.

2. Macroeconomic determinants of agricultural commodity prices. Factors influencing the increase in prices in agricultural markets after 2006

To identify the most important determinants of agricultural commodity prices after 2006 in global context it is worth indicating the macroeconomic price-setting 
factors, which are typical for current economies. These factors include, among others (Abbott, Hurt and Tyner 2008, p. 1, Borensztein and Reinhart 1994, Byrne, Fazio and Fiesse 2011, Grzelak and Stepien 2011, pp. 72-73, Szajner (ed.) 2013, p. 71): (1) the supply-side factors, including available arable land for farmingproduction; the degree of technical and biological progress in agriculture; changes in climate and weather; production costs (in macroeconomic sense, prices of production factors), in which a large role is played by prices of energy and energy resources (prices of oil, natural gas, coal); (2) the demand-side factors, including population; level of economic development and the scale of demand and changes in the structure of consumption; alternative possibilities of use of agricultural land and competition for land between the agri-food market and bio-energy sector; speculation and activity of financial institutions in commodity markets2; (3) other factors, including supply-demand factors and associated with the economic (state) interventionism, which could include the following factors: business cycle and economic activity (price relations in agriculture are dependent on the phase of the business cycle ${ }^{3}$ ); changes in exchange rates; globalization and changes in the macroeconomic environment; economic policy and state interventionism, including:

- fiscal policy by shaping the budget,

- monetary policy, mainly due to (real) interest rates,

- trade policy and its instruments regarding both the export and import,

- exchange rate policy,

- sectoral policies, including the framework of the agricultural policy (it is assumed that the more developed the agricultural policy is, the more it is regulated by a variety of tools, the less is the impact of external factors on the prices of agricultural commodities) and energy policy (changes of this policy, assuming the use of agricultural raw materials for production of bioenergy can have a significant impact on agricultural markets).

The record increases in agricultural commodities' prices that occurred particularly after 2006 were the result of simultaneous existence of numerous factors (figure 2). However it should be emphasized that the impact of these

2 Agricultural raw materials (including wheat) are treated as active, form of investment, and their price may be the underlying instruments for derivative instruments. The increase in the volume of the turnover of speculation contributes to increased volatility of agricultural commodity prices, although it is impossible to determine the extent of this impact (Abbott, Hurt and Tyner 2008, p. 6).

3 More on that topic - see Grzelak 2013, pp. 82-83. 


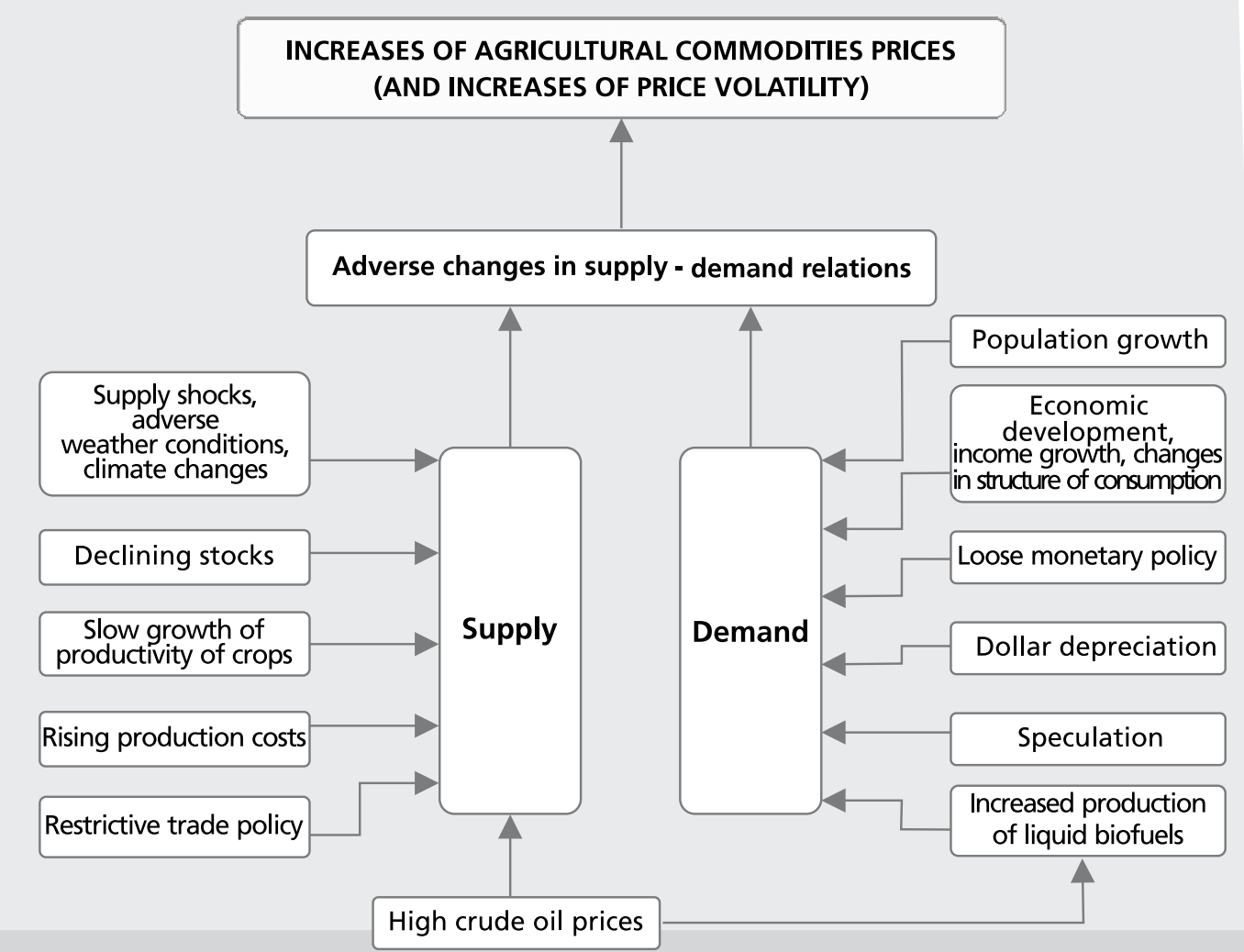

Figure 2. Determinants of increase in agricultural commodity prices after 2006

Source: own study based on consideration in the article and sources used

factors on agricultural prices varied, depending on the specific macroeconomic conditions. These factors are above all:

- adverse global changes of supply-demand relations, affected by changes in both supply-side and demand-side factors,

- development of liquid biofuels sector (biofuels from agricultural raw materials - cereals, edible oils - these are so called the first generation biofuels),

- high and fluctuating crude oil prices,

- expansionary government policy and economic policy, mainly monetary policy and restrictive trade policy,

- depreciation of the dollar,

- growing importance of speculation and activity of investment funds in commodities' markets. 


\subsection{Adverse global changes of supply-demand relations}

One of the key macroeconomic drivers of agricultural commodity price increases after 2006 were, broadly understood, adverse changes in supplydemand relations in world agricultural markets, which included changes on both the supply and the demand side. The first group includes, among others, (1) negative supply shocks as the consequences of climate changes and adverse weather conditions (e.g. drought in Australia, which is the leading producer of cereals in the world, poor harvests in the European Union and Ukraine (2006 and 2007) or crop disease); (2) decrease in stocks of primary agricultural commodities; (3) the slow growth of productivity of crops which was the result of low earlier investments in the development of biological progress in agriculture. These supply shocks and the slow growth in production of agricultural commodities and food had a major impact on agricultural markets, because at the same time stocks were already relatively low and the pressure on price increases was large. In case of high stocks of agricultural products the negative shocks would be offset by surpluses from previous seasons ${ }^{4}$. The state policy should encourage farmers to invest in technical and biological progress in agriculture in periods of high supply, because there is a significant lag between incurring the investment and obtaining results. In addition, it should be considered the low elasticity of supply of agricultural raw materials. On the other hand, among the demand-side factors there should be mentioned the economic growth and development of the countries with a large population (China, India), the increase of incomes and changing consumption patterns, reflected in increased consumption of animal protein instead of vegetable protein, which in turn leads to the higher global demand for agricultural commodities for feed and the issue elasticity of demand for food (which is higher than the elasticity of supply). Above mentioned supplyside and demand-side factors as significant are presented by: P.C. Abbott, C. Hurt and W.E. Tyner (2008), J. Baffes and A. Dennis (2013), J. Baffes and A. Haniotis

4 However, it is worth mentioning that the information coming from the market may affect the participants (buyers and sellers of agricultural raw materials) in such a way that mere signal of an increase of prices can lead to greater demand for raw materials and in fact it makes a pressure on their prices. Thus, the preliminary information, and not the actual events on agricultural markets, may change states of equilibrium in these markets. On the other hand, the real events that will take place later additionally can aggravate the imbalance and even raise prices (Kretschmer, Bowyer and Buckwell 2012). However, Dave (2009) undermines the opinions according to which low stocks were responsible for the increases in food prices over the past decade. 
(2010), Frenkel and Rose (2010), de Gorter and Drabik (2012), Kretschmer, Bowyer and Buckwell (2012), P. Szajner (ed.) (2013) and R. Trostle (2011).

P.C. Abbott, C. Hurt and W.E. Tyner (2008), J. Baffes and A. Dennis (2013) and the authors of the report Food and Agriculture Organization of the United Nations (The State of Agricultural Commodity Markets 2009) argue that the role of China and India in the increases in prices of commodities is interpreted differently and sometimes overrated and misunderstood. The reason for this is the fact that prices of agricultural raw materials are primarily shaped by those countries which are largely involved in trade, while China and India are not among them (with the exception of the fact that China is a big importer of soybeans and vegetable oils, and India is a big exporter of rice). In recent years, these countries were more focused on ensuring the food self-sufficiency. It should be noted that rapidly increasing imports of crude oil to China had an indirect impact on food prices because they affected the world prices of this energy source. Also C. L. Gilbert (2008) points out that the increases of incomes in China did not have the direct impact on agricultural markets. More important is the indirect impact (on oil prices). Thus, the role of these two countries in the increases in raw material prices is diminished.

The development of first-generation liquid biofuels sector (biofuels from agricultural raw materials) is an important demand determinant of increases in commodities prices after 2006. Growing production of bio components increases the competition for agricultural land (between the agri-food market [raw materials for food and feed production] and the biofuels sector) and increases the demand for agricultural commodities. With non-elastic supply in a short period, it leads to prices increase, which concerns especially cereals and oilseeds. The biofuels policy is considered as a source of the problem, because it promotes the use of agricultural raw materials for energy purposes (often in the form of obligatory shares of biofuels in total transport fuel consumption) and unreasonably supporting by various instruments of fiscal policy. Thereby raising production of bio components becomes an important additional factor influencing agricultural commodities' prices (Abbott, Hurt and Tyner 20086, Gilbert 2008, pp. 11-14, Kim et al. 2013, p. 60, Kretschmer, Bowyer and Buckwell

5 These instruments can be subsidies or tax reliefs for producers of bio components.

6 These authors estimate that the increases in corn prices in the United States at 25\% were due to the increase of bioethanol production. At the same time they believe that the raising production of biofuels was one of the three main drivers of growth in commodity prices after 2006 (other causes were unfavourable changes in supply-demand relations and the depreciation of the dollar). 
2012, pp. 28-31, Krugman 2008a', Mitchell 20088, Szajner (ed.), 2013, pp. 71-73, The State of Agricultural Commodity Markets 2009, pp. 15-25, Trostle et al. 2011).

However, some authors argue that the increase in biofuels production had an insignificant influence on agricultural markets, but this influence is intentionally overestimated. It is in fact lower than generally assumed and biofuels production was one of the least important reasons for the price increases (Baffes and Dennis 2013, Oladosu and Msangi 2013, p. 54, Prandecki and Floriańczyk 2014, p. 25, Szajner (ed.), 2013b, von Witzke and Noleppa 2011). The arguments for this position are as follows (Baffes and Haniotis 2010): (1) used arable land and consumption of agricultural commodities for biofuel targets is too small to be able to put pressure on their prices; (2) fluctuations of prices are results of many factors, and they do not change adequately to changes in the biofuel sector.

\subsection{Increases in crude oil prices}

An important factor for agricultural commodities' prices increases in recent years were high oil prices and their high volatility. Although the force of its impact (on commodities prices) depends on the energy consumption in agriculture relative to other sectors of the economy, there is no doubt, however, that crude oil prices are one of the key price-setting factors. Price increases of this energy source cause increases of the production costs of agricultural raw materials (due to the more expensive fertilizers, fuels, chemicals and others), which in turn reduces the supply of raw materials and leads to prices increases as the mechanism was described by K. Hanson, S. Robinson and G. Schluter (1993) and P. C. Abbott, C. Hurt and W. E. Tyner (2008). Currently, an additional problem may be uncertainty about oil extraction as a result of political conflicts. It might limit its supply and consequently rise the prices. The mentioned high

7 Paul Krugman concludes that countries with his biofuels policy (policy supporting biofuels sector) should withdraw from them because its implementation was the wrong decision, and its consequences were rising prices of agricultural commodities and food.

8 The author explains that the dynamic growth in demand for agricultural commodities resulting from the development of liquid biofuels caused the increases in agricultural commodity prices. In 2004-2007, corn use for feed increased by $1.5 \%$, while corn use for energy by as much as $65 \%$. On the other hand, a significant part $(70 \%)$ of increase in corn production was allocated for energy purposes. It should be noted that by price spikes of corn in the United States, there were also price increases of other commodities, such as soy, wheat, rice, because it changed the structure of crops. Thus, an increase in the biofuels production had both direct and indirect impact on the price increases of various agricultural raw materials. 
price volatility of crude oil may result in high volatility of prices of agricultural commodities and food (but also non-agricultural commodities, metals).

Based on data from the period 1960-2008 and using an econometric model, J. Baffes (2009) analysed the relationship between prices of energy resources (crude oil, natural gas and coal) and non-energy commodities' prices (agricultural raw materials and food, metals and fertilizer). His results clearly indicate that this relationship is positive and the elasticity is 0.28 , which means that the increase in prices of energy resources causes increases in non-energy commodities' prices in general. Elasticity for relation: prices of energy and food prices is 0,27. S. M. Obadi and M. Korcek (2014) conducted a broad and detailed analysis of the impact of crude oil prices on the prices of food and agricultural commodities (sugar, poultry, barley, corn, palm oil, wheat, rice) for the period 1975 to 2013. The authors convince that the most important factor of the growing agricultural commodity prices were increases in crude oil prices, as the main production cost in the agriculture. In addition, they suggest that oil prices affect prices of agricultural commodities, but this relationship, with the exceptions, does not work in the opposite direction.

J. Baffes and A. Dennis (2013) in their research concluded that increases in crude oil prices were the main driver of growth in agricultural commodity prices in recent years (about $50 \%$ of price increases are accounted for by crude oil prices). Also other authors indicate that the above-described sequence of cause and effect and the transmission of price impulses of crude oil to agricultural raw materials occurred after 2006 (Gilbert 2008, Krugman 2008a, The State of Agricultural Commodity Markets 2009, Trostle 2008, Trostle et al. 2011, von Witzke and Noleppa 2011). The impact of prices of energy (and energy resources) on commodities' prices becomes stronger, when energy markets and non-energy commodities' markets are more integrated (Baffes and Haniotis 2010). C. L. Gilbert (2008) further notes that, in case of integration and strong linkages of these markets, the transmission of impulses can be fast. The link between oil prices with the prices of agricultural products is also indicated by: J. Baffes and T. Haniotis (2010), M. Hamulczuk and C. Klimkowski (2012), I. S. Kim et al. (2013), J. Piesse and C. Thirtle (2009, p. 122, 127), S. H. Saghaian (2010), T. Serra (2011), P. Szajner (ed.) (2013). The State of Agricultural Commodity Markets (2009, p. 21). Although Gilbert (2008) indicates the existence of a weak dependence (expressed low value of the correlation coefficient) between real oil prices and real commodities' prices, it seems that this relationship is relatively strong. In fact, the correlation coefficient between Oil Price Index and Food 
Price Index (based on FAO data) for the period 1990-2015 amounts 0.91, and for the period 2002-2014 amounts 0.94, which belies the opinion formulated by the British economist.

\subsection{Loose economic policy and restrictions in trade policy}

Expansionary economic policies, mainly monetary but also fiscal and restrictive trade policy favour growth of prices (Baffes and Haniotis 2010). A monetary expansion expressed, inter alia, by the low interest rates, was one of the key drivers of food and commodity prices after 2006, which showed the British economist C. L. Gilbert (2008, pp. 28-29) in their study based on the Granger causality test. The importance of monetary policy was also emphasized by J. Frenkel and A. K. Rose (2010), H. de Gorter and D. Drabik (2012, p. 22) and J. P. Byrne et al. (2011), pointing to the simple negative correlation between the level of real interest rates and the prices of agricultural commodities. These latter authors stress the significant role and task of monetary policy in creating a stable level of prices of raw materials as well as finished goods.

In turn J. Baffes and T. Haniotis (2010), H. de Gorter and D. Drabik (2012, p. 22), R. Trostle (2008) and H. von Witzke and S. Noleppa (2011) point to the great importance of restrictions in the trade policy for the growth of agricultural commodity prices after 2006. It should be emphasized that rapid changes in trade policy and the sudden restriction in international trade in agricultural commodities and food can lead to fluctuations in global agricultural markets, which can affect price changes. Above mentioned authors argue that export bans and high tariffs, as well as export taxes led to reduction in the supply and the emergence of pressure on price increases of agricultural products. B. Kretschmer, C. Bowyer and A. Buckwell (2012, pp. 29-30) prove that trade policy (and its restrictive changes) has been important in the growth of world agricultural commodity prices in recent years, especially wheat and rice. These instruments bring admittedly rather short-term effect, but in consequence they may lead to changes in the structure of production, which in turn can have an impact on prices in the long term. The future significance of this factor is very difficult to estimate, because governments can make decisions in an unpredictable way, but also as a reaction to the actions of governments of other countries or integration groups, thus changes in trade policy will remain a relatively important factor for global agricultural markets.

Determinants of prices increase

of agricultural commodities in a global 


\subsection{Depreciation of the dollar and the growing importance of speculation and activity of investment funds in commodities' markets}

As explained by B. Kretschmer, C. Bowyer and A. Buckwell (2012, p. 30), currently most commodities are denoted and traded in US Dollars. If there is a depreciation of the dollar (and this took place in the period 2007-2008), the agricultural commodities become relatively cheaper in other currencies. This in turn results in an increase in demand for these commodities, which, with a constant supply (resulting from the rigidity of supply), leads to increases of their prices. It is difficult or even impossible to estimate the future impact of this factor on agricultural markets (and commodities' prices), because exchange rates are shaped by a number of macroeconomic factors both endogenous and exogenous. For this reason, fluctuations in exchange rates may remain a key factor determining the prices of agricultural raw materials in the future.

P. C. Abbott, C. Hurt and W. E. Tyner (2008) clearly indicate that the depreciation of the dollar (against the euro and other currencies) has been during the period of commodity price increases one of the three key factors, and that it resulted from growing demand for agricultural commodities from the United States and rising crude oil prices. These scientists imply that many authors do not appreciate this factor for the increase in commodities' prices, even confusing cause and effect. For example, C. L. Gilbert (2008) adopts exchange rates movements as unimportant during the recent rises in commodities' prices. However J. Baffes and A. Dennis (2013) ${ }^{9}$, J. Baffes and T. Haniotis (2010), H. de Gorter and D. Drabik (2012, p. 22), H. von Witzke and S. Noleppa (2011) and R. Trostle al. (2011) consider depreciation of the dollar as a significant driver of commodities and food prices.

The activity of financial institutions in agricultural markets is reflected by the inclusion of agricultural raw materials for the investment portfolio, which can trigger actions partly speculative and create asset bubbles. According to J. Baffes and T. Haniotis (2010) financial institutions, to some extent, were responsible for increases in agricultural commodity prices, as it was so called "financialization of commodities". In addition, P. C. Abbott, C. Hurt and W. E. Tyner (2008) argue that speculation contributed to the increase in the volatility of commodities' prices. Speculation unreally inflates the price of raw materials, e.g. through speculative activities on the stock markets or by derivatives trade outside exchanges. Their

9 These scientists from the World Bank in the report on long-term drivers of food prices emphasize that exchange rates movements accounted for approximately $15 \%$ of the increase in food prices. 
importance in recent years was emphasized by J. Frenkel and A. K. Rose (2010), H. de Gorter and D. Drabik (2012, p. 22), P. Krugman (2008b) and A. Skarżyńska (ed.) (2012, p. 117).

C. L. Gilbert (2008) does not agree with that opinion and convinces that it is not speculators who were responsible for the increases of agricultural commodity price, but the commodities' investors, who raised the prices through their investments. B. Kretschmer, C. Bowyer and A. Buckwell (2012, p. 30) and P. Szajner (ed.) (2013, p. 73) agree generally with that view, however they argue that speculation and activities of financial institutions in this area are difficult in unambiguous interpretation. On the one hand, they could be the cause of rising prices, but on the other hand, it is possible that "speculative flows into agricultural future markets follow the increases in commodities' prices", thus speculation was not the primary cause. Nevertheless, the increase in the volume of sales of a speculative nature may lead to increased prices of agricultural products and can increase their volatility. The role of speculation in the rise of agricultural commodity prices in turn was depreciated by H. von Witzke and S. Noleppa (2011), arguing that it is not justified to assign the speculation the great importance as a driver of agricultural commodity prices. They prove that the growth in raw material prices that took place especially in the years 2007-2008 was the complex of many factors, and the role of speculation in this area was small.

\section{Conclusions}

In 2008 and 2011 there were broad increases in the prices of most agricultural commodities globally. They were results of both supply-side and demand-side factors. The second figure shows factors which were the most important for the growth of commodities' prices after 2006. In the authors' opinion the most relevant factors were adverse changes in supply-demand relations, increasing crude oil prices, exchange rates movements and speculations. An inappropriate economic policy also had significance. According to the authors loose economic policy and restrictions in trade policy were less important. The changes in supply-demand relations were results of several factors. Growing incomes of societies in the developing countries led to the changes in structure of consumption (towards greater consumption of animal protein) and a low level of stocks deepened the problem.

An increasing biofuels production has influence on agricultural commodity markets in two dimensions. There were prices increases of these agricultural 
raw materials, which are used for biofuels production (direct influence) and other commodities, because changes in structure of crops were observed and the supply of these commodities decreased (indirect influence). In such a situation biofuels production had both a direct and indirect impact on the prices increases of many agricultural raw materials. The issue of biofuels is all the more serious that their production has often no economic justification and its development is stimulated by administrative instruments. Thus biofuel policies caused additional demand for agricultural commodities and led to an increase in their prices. One of the most important factors for prices increases after 2006 were growing crude oil prices. These prices are crucial for agricultural production costs and for prices of raw materials and food (as well as many other products). In addition, rising crude oil prices encouraged the increase of biofuels production, which further stimulated increases in commodities' prices.

According to the authors exchange rates movements and speculations were important too. An increasing activity of financial funds on agricultural markets led to higher demand for agricultural raw materials and thus affected higher prices of commodities and food prices. What is more, the prices volatility increased and the problem was compounded by exchange rates fluctuations. A similar situation concerned crude oil and its prices. Financial institutions intended to invest in crude oil prices for high profits (higher that in the stock market), however the supply grew not as rapidly as the demand for this energy source. It caused that oil prices were more than twice as high in relation to the equilibrium prices. This justifies the importance of speculations in prices increases of agricultural raw materials.

\section{Summary}

\section{Determinants of prices increase of agricultural commodities in a global context}

The main objective of this article is to present the determinants of increase in agricultural commodity prices after 2006. The other specific aim is to show the factors affecting agricultural raw materials and food prices in the global context. This article is a review paper of the determinants of recent commodity and food prices spikes. However, it provides an outlook on these determinants that were the most important for the increases in the last decade. The last part of the article (conclusions) to some extent is a synthesis of considerations and includes the authors' opinions concerning determinants and an attempt to 
identify which ones were the most important in the growth of agricultural commodity prices. These increases in agricultural commodity prices resulted from many factors and it is very difficult to separate the individual impact of each of them, because they occurred in parallel. However, it is possible to indicate several main reasons for these price increases, which are: adverse changes in supply-demand relations in agricultural markets, increases in oil prices (and increases of the volatility of those prices), development of biofuel production from agricultural commodities (the first generation biofuels), dollar depreciation, an increase in operations of a speculative nature on commodity markets and improper economic policy that created an environment for the growth of prices of agricultural products.

Keywords: agricultural raw materials, agricultural commodities, determinants of increase of agricultural commodity prices, supply-demand relations, oil prices, biofuels, dollar depreciation, speculation on agricultural markets, monetary policy, trade policy

\section{Streszczenie}

\section{Determinanty wzrostu cen surowców rolnych $\mathrm{w}$ warunkach globalnych}

Celem głównym artykułu jest ukazanie determinant wzrostu cen surowców rolnych, które szczególnie zaznaczyły się w ich wzrostach po 2006 roku. Jego realizację wspiera cel podrzędny, którym jest przedstawienie makroekonomicznych czynników cenotwórczych na rynkach rolnych. Artykuł ma charakter przeglądowy, z którego wynikają jednak pewna ocena oraz pogląd na te determinanty, które dla wzrostów cen produktów rolnych były najistotniejsze. Podsumowanie stanowi syntezę rozważań i zawarto $\mathrm{w}$ nim opinie autorów dotyczące poszczególnych determinant wraz $\mathrm{z}$ próbą wskazania, które $\mathrm{z}$ nich miały największe znaczenie we wzrostach cen surowców rolnych. Wzrosty cen surowców rolnych $\mathrm{w}$ ostatnich latach wynikały $\mathrm{z}$ działania wielu czynników i $\mathrm{w}$ gruncie rzeczy trudno jest wyizolować osobny wpływ każdego z nich, ponieważ czynniki te występowały równolegle. Można natomiast wskazać główne determinanty tych wzrostów cen, są nimi: niekorzystne zmiany 
relacji podażowo-popytowych na rynkach rolnych, wzrosty cen ropy naftowej (i wzrosty zmienności tych cen), rozwój produkcji biopaliw z surowców rolnych, deprecjacja dolara, wzrost działań o charakterze spekulacyjnym na rynkach towarowych oraz niewłaściwa polityka gospodarcza, która stworzyła środowisko dla wzrostu cen produktów rolnych.

Słowa

kluczowe: surowce rolne, determinanty wzrostu cen surowców rolnych, relacje podażowo-popytowe, ceny ropy naftowej, biopaliwa, deprecjacja dolara, spekulacje na rynkach rolnych, polityka pieniężna $i$ handlowa

\section{References}

1. Abbott P. C., Hurt C., Tyner W. E., (2008), What's Driving Food Prices?, Farm Foundation Issue Report, Oak Brook, IL.

2. Baffes J., (2009), More on the Energy/Non-Energy Commodity Price Link, The World Bank, Development Prospects Group, Global Trends Team, Policy Research Working Paper 4982, Washington.

3. Baffes J., Dennis A., (2013), Long-Term Drivers of Food Prices, The World Bank, Development Prospects Group \& Poverty Reduction and Economic Management Network, Trade Department, Policy Research Working Paper 6455, Washington.

4. Baffes J., Haniotis T., (2010), Placing the 2006/08 Commodity Price Boom into Perspective, The World Bank, Development Prospects Group, Policy Research Working Paper 5371, Washington.

5. Borensztein E., Reinhart C., (1994), The Macroeconomic Determinants of Commodity Prices, International Monetary Fund Staff Papers, vol. 41, No. 2.

6. Byrne J. P., Fazio G., Fiess N., (2011), Primary Commodity Prices: Comovements, Common Factors and Fundamentals, The World Bank, Latin America and Caribbean Region, Economic Policy Sector, Policy Research Working Paper 5578, Washington.

7. Dave D., (2009), The Unimportance of "Low” World Grain Stocks for Recent World Price Increases, ESA Working Paper No. 09-01, Agricultural Development Economics Division, Food and Agriculture Organization of the United Nations, Rome.

8. Food and Agriculture Organization of the United Nations, World Food Situation, FAO Food Price Index, http://www.fao.org/ worldfoodsituation/foodpricesindex/en/ (data dostępu: 1.10.2015).

9. Frenkel J., Rose A. K., (2010), Determinants of Agricultural and Mineral Commodity Prices, w: Fry R., Jones C., Kent C., Inflation in an era of Relative 
price shocks, Reserve Bank of Australia, Centre for Applied Macroeconomic Analysis, Sydney.

10. Gilbert C. L., (2008), How to Understand High Food Prices, Journal of Agricultural Economics, vol. 61, maszynopis.

11. de Gorter H., Drabik D., (2012), The effect of biofuel policies on food grain commodity prices, Biofuels, Volume 3, Issue 1.

12. Grzelak A., (2013) Sytuacja ekonomiczna gospodarstw rolnych w warunkach zmiany koniunktury gospodarczej (2007-2009), Roczniki Ekonomii Rolnictwa i Rozwoju Obszarów Wiejskich, t. 100, z. 1.

13.Grzelak A., Stępień S., (2011), Uwarunkowania i skutki zmian klimatycznych dla sektora rolnego - aspekty ekonomiczne, w: Zegar J. S. (red.), Z badań nad rolnictwem społecznie zrównoważonym (11), Program Wieloletni 2011-2014, nr 3, IERiGŻ-PIB, Warszawa.

14. Hamulczuk M., Klimkowski C., (2012), Response of the Polish Wheat Prices to the World's Crude Oil Prices, Acta oeconomica et informatica, vol. 15, no. 2.

15. Hanson K., Robinson S., Schluter G., (1993), Sectoral Effects of a World Oil Price Shock: Economywide Linkages to the Agricultural Sector, Journal of Agricultural and Resource Economics 18 (1).

16. Kim I. S., Binfield J., Patton M., Zhang L., Moss J., (2013), Impact of increasing liquid biofuel usage on EU and UK agriculture, Food Policy, Vol. 38.

17. Kretschmer B., Bowyer C., Buckwell A., (2012), EU Biofuel Use and Agricultural Commodity Prices: A Review of the Evidence Base, Report prepared for Action Aid, Institute for European Environmental Policy, London.

18. Krugman P., (2008a), Grains Gone Wild, Op-Ed Columnist, New York Times 7.04.2008. http://www.nytimes.com/2008/04/07/opinion/07krugman. html (data dostępu: 4.10.2015).

19. Krugman P., (2008b), Running Out of Planet to Exploit, Op-Ed Columnist, New York Times 21.04.2008. http://www.nytimes.com/2008/04/21/ opinion/21krugman.html?_r=0 (data dostępu: 1.10.2015).

20. Mitchell D., (2008), A Note on Rising Food Prices, The World Bank, Development Prospects Group, Policy Research Working Paper 4682, Washington.

21. Obadi S. M., Korcek M., (2014), Are Food Prices Affected by Crude Oil Price: Causality Investigation, Review of Integrative Business and Economics Research, Vol. 3, Issue 1.

22. Oladosu G., Msangi S., (2013), Biofuel-Food Market Interactions: A Review of Modeling Approaches and Findings, Agriculture no 3.

23. Piesse J., Thirtle C., (2009), Three bubbles and a panic: An explanatory review of recent food commodity price events, Food Policy, Volume 34, Issue 2.

24. Prandecki K., Floriańczyk Z., (2014), Z badań nad rolnictwem społecznie zrównoważonym (28). Produktywność różnych form rolnictwa zrównoważonego, Program Wieloletni 2011-2014, nr 137, IERiGŻ-PIB, Warszawa. 
25. Saghaian S. H., (2010), The Impact of the Oil Sector on Commodity Prices: Correlation or Causation?, Journal of Agricultural and Applied Economics, Volume 42, Number 03.

26. Serra T., (2011), Volatility spillovers between food and energy markets: A semiparametric approach, Energy Economics, Volume 33, Issue 6.

27. Skarżyńska A. (red.) (2012), Nadwyżka bezpośrednia z wybranych produktów rolniczych w 2011 roku oraz projekcja dochodów w perspektywie średnioterminowej, Program Wieloletni 2011-2014, nr 55, IERiGŻ-PIB, Warszawa.

28. Szajner P. (red.) (2013a), Sytuacja na światowym rynku cukru i jej wpływ na możliwości uprawy buraków cukrowych w Polsce, Program Wieloletni 20112014, nr 71, IERiGŻ-PIB, Warszawa.

29. Szajner P. (red.) (2013b), Światowa produkcja biopaliw w kontekście bezpieczeństwa żywnościowego, Program Wieloletni 2011-2014, nr 70, IERiGŻ-PIB, Warszawa.

30. The State of Agricultural Commodity Markets: High food prices and the food crisis - experiences and lessons learned, (2009), Food and Agriculture Organization of the United Nations, Rome.

31. Trostle R., (2008), Global Agricultural Supply and Demand: Factors Contributing to the Recent Increase in Food Commodity Prices, A Report from the Economic Research Service, United States Department of Agriculture, Washington.

32. Trostle R., Marti D., Rosen S., Westcott P., (2011), Why Have Food Commodity Prices Risen Again?, A Report from the Economic Research Service, United States Department of Agriculture, Washington.

33. von Witzke H., Noleppa S., (2011), Why speculation is not a prime cause of high and volatile international agricultural commodity prices: An economic analysis of the 2007-08 price spike, The economics of Rumpelstiltskin, Humboldt Forum for Food and Agriculture, Berlin. 